Article

\title{
Low Dielectric Loss and Multiferroic Properties in Ferroelectric/Mutiferroic/Ferroelectric Sandwich Structured Thin Films
}

\author{
Zhi-Yong $\mathrm{Wu}^{1, *}$ and Cai-Bin $\mathrm{Ma}^{2}$ \\ 1 College of Traditional Chinese Medicine, Southern Medical University, Guangzhou 510515, China \\ 2 School of Physics \& Optoelectric Engineering, Guangdong University of Technology, Guangzhou Higher \\ Education Mega Centre, Guangzhou 510006, China \\ * Correspondence: wuzhiyong608@163.com; Tel./Fax: +86-20-6278-7160
}

Received: 13 July 2019; Accepted: 6 August 2019; Published: 8 August 2019

\begin{abstract}
Bismuth ferrite $\left(\mathrm{BiFeO}_{3}\right)$ has proven to be promising for a wide variety of microelectric and magnetoelectric devices applications. In this work, a dense $\left(\mathrm{Ba}_{0.65} \mathrm{Sr}_{0.35}\right) \mathrm{TiO}_{3}(\mathrm{BST}) /$ $\left(\mathrm{Bi}_{0.875} \mathrm{Nd}_{0.125}\right) \mathrm{FeO}_{3}(\mathrm{BNF}) / \mathrm{BST}$ trilayered thin film grown on Pt-coated Si (100) substrates was developed by the rf-sputtering. For comparison, single-layered BNF and BST were also prepared on the same substrates, respectively. The results show that the dielectric loses suppression in BST/BNF/BST trilayered thin films at room temperature but has enhanced ferromagnetic and ferroelectric properties. The remnant polarization $\left(P_{\mathrm{r}}\right)$ and coercive electronic field $\left(E_{\mathrm{c}}\right)$ were $5.51 \mu \mathrm{C} / \mathrm{cm}^{2}$ and $18.3 \mathrm{kV} / \mathrm{cm}$, and the remnant magnetization $\left(M_{\mathrm{r}}\right)$ and coercive magnetic field $\left(H_{\mathrm{c}}\right)$ were $10.1 \mathrm{emu} / \mathrm{cm}^{3}$ and $351 \mathrm{Oe}$, respectively, for the trilayered film. We considered that the bismuth's volatilization was limited by BST bottom layers making the Bi/Fe in good station, and the action of BST layer in the charge transfer between BNF thin film and electrode led to the quite low leakage current and enhanced multiferroic property. The origin of the mechanism of the highly enhanced dielectric constant and decreased loss $\tan \delta$ was discussed.
\end{abstract}

Keywords: multiferroic thin films; low dielectric loss; leakage current; ferromagnetic; ferroelectric

\section{Introduction}

Multiferroic (MF) materials, such as bismuth ferrite $\mathrm{BiFeO}_{3}(\mathrm{BFO})$, have been widely studied due to their potential applications for ferroelectric (FE) memories, piezoelectric sensor, and magnetoelectric devices [1-3]. Due to a large spontaneous polarization, a high Curie temperature $\left(T_{C}=1103 \mathrm{~K}\right)$, and a high Neel temperature $\left(T_{N}=643 \mathrm{~K}\right), \mathrm{BFO}$ has fascinated researchers since it was first synthesized. However, BFO has remained unsuitable, due to its high leakage current and large dielectric loss [4-6]. Magnetic properties can be adjusted by using $\mathrm{Nd}^{3+}$ ions instead of larger $\mathrm{Bi}^{3+}$ ions in the $\mathrm{BFO}$ composition [7], and in order to improve leakage current, $\mathrm{Ni}$, Ti, Sm, Mn, $\mathrm{Zn}$, and Ho doped in BFO thin films [8-14], to improve ferroelectric properties and ferroelectric properties, but there was limited action in reducing leakage current. Due to its nonlinear dielectric properties, $(\mathrm{Ba}, \mathrm{Sr}) \mathrm{TiO}_{3}$ has been widely used in electronic devices [15-17]; however, there is low remnant polarization and coercive electric field in the $(\mathrm{Ba}, \mathrm{Sr}) \mathrm{TiO}_{3}$ thin film. In order to improve the electrical properties of MF films, the electrical properties and MF properties of MF films can be controlled by interfacial layer. Miao et al. explained the enhanced fatigue properties in $\mathrm{MF}(\mathrm{Ba}, \mathrm{Sr}) \mathrm{TiO}_{3} /(\mathrm{Bi}, \mathrm{La}) \mathrm{FeO}_{3}$ thin films [18]; Feng et al. reported the electrical properties of $\mathrm{BiFeO}_{3}$ thin film with a $\mathrm{BaTiO}_{3}\left(\right.$ or $\left.\mathrm{SrTiO}_{3}\right)$ buffer layer [19]; and Zhang et al. reduced the leakage current density in $\mathrm{Bi}_{2} \mathrm{NiMnO}_{6}$ thin films with double $\mathrm{SrTiO}_{3}$ layers [20]. Guo et al. improved the switching speed of $\mathrm{BiFeO}_{3}$ capacitors by electrodes' conductivity and magnetic 
fields [21,22]. The electric field control of magnetism requires deterministic control of the magnetic order, and the magnetoelectric coupling in multiferrous $\mathrm{BiFeO}_{3}$ can be understood [23]. In addition, the others $\mathrm{FE} / \mathrm{MF}$ heterostructured thin films and $\mathrm{FE} / \mathrm{MF}(\mathrm{FE}) / \mathrm{FE}$ trilayered structural thin films were prepared [24-27], but these films still have a high leakage current density and a dissipation factor.

In this work, $\mathrm{Ba}_{0.65} \mathrm{Sr}_{0.35} \mathrm{TiO}_{3}, \mathrm{Bi}_{0.875} \mathrm{Nd}_{0.125} \mathrm{FeO}_{3}$ and $\mathrm{Ba}_{0.65} \mathrm{Sr}_{0.35} \mathrm{TiO}_{3}-\mathrm{Bi}_{0.875} \mathrm{Nd}_{0.125} \mathrm{FeO}_{3}-$ $\mathrm{Ba}_{0.65} \mathrm{Sr}_{0.35} \mathrm{TiO}_{3}$ thin films grown on $\mathrm{Pt} / \mathrm{Ti} / \mathrm{SiO}{ }_{2} / \mathrm{Si}(100)$ substrates were prepared by radio frequency magnetron sputtering. The ferroelectric, ferromagnetic, and electrical properties of these film samples were investigated. The low dielectric loss, low leakage current density, and multiferroic properties enhancement mechanism of the sandwich structural thin films are also discussed.

\section{Materials and Methods}

The single-layered $\mathrm{Ba}_{0.65} \mathrm{Sr}_{0.35} \mathrm{TiO}_{3} \quad(\mathrm{BST}), \quad \mathrm{Bi}_{0.875} \mathrm{Nd}_{0.125} \mathrm{FeO}_{3} \quad(\mathrm{BNF})$, and trilayered $\mathrm{BST}(50 \mathrm{~nm}) / \mathrm{BNF}(50 \mathrm{~nm}) / \mathrm{BST}(50 \mathrm{~nm})$ thin films grown on $\mathrm{Pt}(111) / \mathrm{Ti} / \mathrm{SiO}_{2} / \mathrm{Si}(100)$ substrates using radio frequency magnetron sputtering with ceramic targets of BNF and BST [28,29]. When BST and BNF thin films sputter, the maintenance of $500{ }^{\circ} \mathrm{C}$ is the ideal substrate temperature, and $\mathrm{Ar} / \mathrm{O}_{2}$ (pressure ratio 9:1) and nitrogen are the ideal deposition atmosphere, respectively [30]. We annealed the samples at $650^{\circ} \mathrm{C}$ by use of a rapid thermal annealing (RTA) furnace. The preparation of a three-layer heterostructure BST/BNF/BST film was completed. By comparison, a BST and BNF thin film with a thickness of $150 \mathrm{~nm}$ was also achieved. For electrical measurements, we adopted a vacuum evaporation to deposited $0.2 \mathrm{~mm}$ diameter top gold $(\mathrm{Au})$ electrodes onto the BST and BNF and BST/BNF/BST thin films, respectively. The thickness of the thin films on $\mathrm{Pt}(111) / \mathrm{Ti} / \mathrm{SiO}_{2} / \mathrm{Si}(100)$ substrates was measured by a surface profiler (KLA-Tencor P-10, Class One Equipment Inc., Decatur, GA, USA), which was about $150 \mathrm{~nm}$. The crystal structure of the BNF, BST and BST/BNF/BST thin films were characterized by X-ray diffraction (XRD) (D-MAX 2200, Rigaku, Tokyo, Japan) with automated powder diffractometer 1710 (PANalytical B.V., Almelo, Netherlands) in $\theta-2 \theta$ configuration with $\mathrm{Cu} \mathrm{K} \alpha(\lambda=1.5406 \AA)$ radiation. The surface and cross-sectional images were probed by field emission scanning electron microscope (FESEM, S-4800, Hitachi, Tokyo, Japan) with 1 and $5 \mathrm{kV}$, respectively. We measured the dielectric properties of $\mathrm{Au} / \mathrm{BST} / \mathrm{Pt}, \mathrm{Au} / \mathrm{BNF} / \mathrm{Pt}$, and $\mathrm{Au} / \mathrm{BST} / \mathrm{BNF} / \mathrm{BST} / \mathrm{Pt}$ capacitors by means of Agilent $4284 \mathrm{~A}$ impedance analyzers (Shenzhen Shunyuanda Technology Co., Ltd., Shenzhen, China) under room temperature. FE properties were measured using Precision premier II ferroelectric tester (Agilent Technologies Inc., Santa Clara, CA, USA), and the ferromagnetic properties were characterized by Magnetic Property Measurement system MPMS XL-7 (Quantum Design, San Diego, CA, USA).

\section{Results and Discussion}

Figure 1 illustrates the XRD patterns of the three BNFs, BSTs, and BST/BNF/BST thin films were grown on $\mathrm{Pt}(111) / \mathrm{Ti} / \mathrm{SiO}_{2} / \mathrm{Si}(100)$ substrates, respectively. When the $\mathrm{BNF}$ film was annealed at $650{ }^{\circ} \mathrm{C}$ with nitrogen atmosphere, the film sample (see Figure 1a) crystallized a pure rhombohedral (R3c) distorted perovskite structure [29]. In addition, the BST film was annealed at $650{ }^{\circ} \mathrm{C}$, the film crystallized a pure cubic perovskite structure (see Figure 1b). From Figure $1 b, c$, it is can be seen that BST was used as buffer-layer, the BNF films grown on $\mathrm{Pt} / \mathrm{Ti} / \mathrm{SiO}_{2} / \mathrm{Si}(100)$ substrate with pseudocubic phase was annealed at $650{ }^{\circ} \mathrm{C}$ in oxygen atmosphere. From Figure 1, these in-plane lattice parameters of bottom BST, BNF, and top BST thin films were obtained; the results were 4.001(4), 3.961(1), and 3.996(4) A, respectively for bottom BST, BNF and top BST thin film. Stryukov et al. reported that when the $\mathrm{Bi}_{0.98} \mathrm{Nd}_{0.02} \mathrm{FeO}_{3}$ thin films growth on the $\mathrm{Ba}_{0.8} \mathrm{Sr}_{0.2} \mathrm{TiO}_{3}$ buffer-layer with tetragonal phase, the heterostructures $\mathrm{Bi}_{0.98} \mathrm{Nd}_{0.02} \mathrm{FeO}_{3} / \mathrm{Ba}_{0.8} \mathrm{Sr}_{0.2} \mathrm{TiO}_{3}$ on (100)MgO substrate has a monoclinic structure with the space group Cc at room temperature [29]. Thus, the BST layer is conducive to the growth of BNF crystals. The BST and BST/BNF/BST thin films display polycrystalline structure and without any secondary phases. Typically, the BNF film is annealed in an oxygen atmosphere and a second phase appears [30]. The crystal structure of the BNF thin films can be controlled by using BST buffer-layer and annealing atmosphere. 


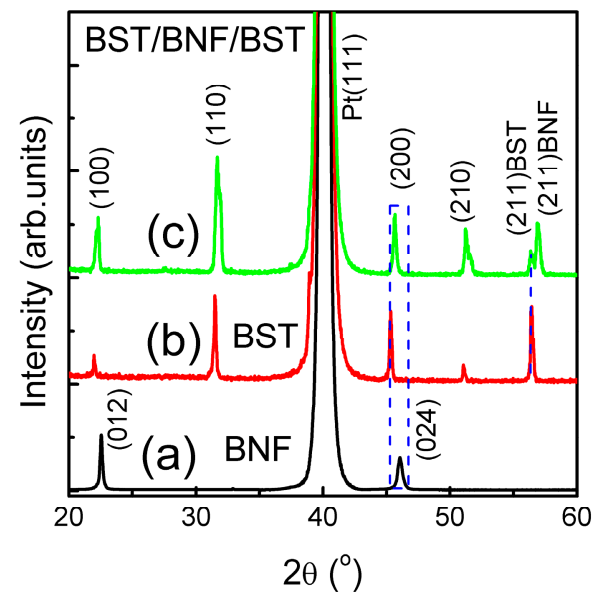

Figure 1. XRD patterns of (a) BNF, (b) BST, and (c) BST/BNF/BST thin films on $\mathrm{Pt}(111) / \mathrm{Ti} / \mathrm{SiO}_{2} / \mathrm{Si}(100)$ substrates. When BST and BNF thin films sputter, the maintenance of $500{ }^{\circ} \mathrm{C}$ is the ideal substrate temperature, and $\mathrm{Ar} / \mathrm{O}_{2}$ (pressure ratio 9:1) and nitrogen are the ideal deposition atmosphere, respectively. We annealed the samples at $650{ }^{\circ} \mathrm{C}$ by use of a rapid thermal annealing (RTA) furnace.

The FESEM morphologies of BST/BNF/BST heterostructure film on $\mathrm{PT} / \mathrm{Ti} / \mathrm{SiO}_{2} / \mathrm{Si}(100)$ substrate annealed at $650^{\circ} \mathrm{C}$ for $30 \mathrm{~min}$ in oxygen atmosphere was shown in Figure 2. The results show that the structure of the film is dense and uniform. $20 \mathrm{~nm}$ is about the average particle size. The thickness of BST at the bottom, BNF at the middle, and BST at the top are $\sim 50,50$, and $50 \mathrm{~nm}$, respectively. The result is consistent with the measurement by the surface profiler.

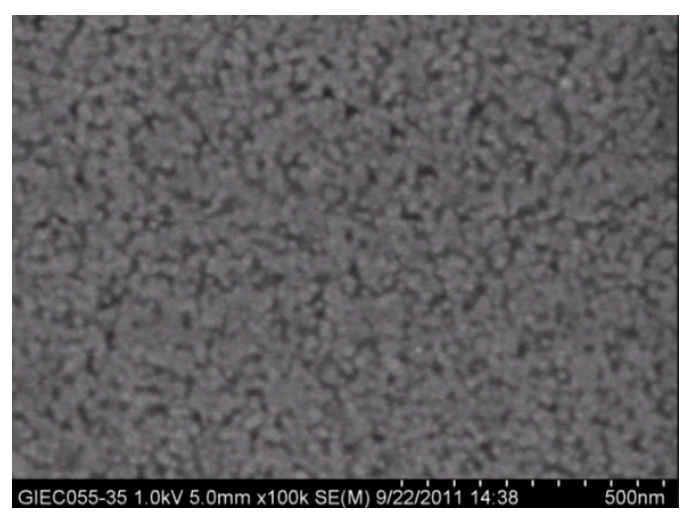

(a)

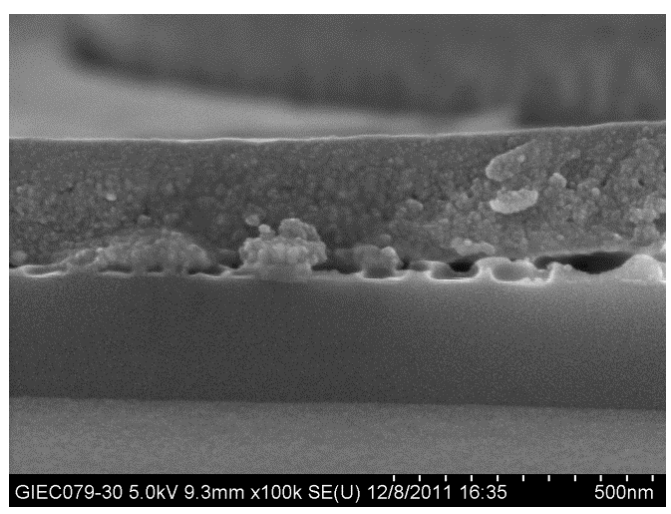

(b)

Figure 2. The SEM images of surface (a) and cross-section (b) of the BST/BNF/BST films on $\mathrm{Pt}(111) / \mathrm{Ti} / \mathrm{SiO}_{2} / \mathrm{Si}(100)$ substrates annealed $650{ }^{\circ} \mathrm{C}$ for $30 \mathrm{~min}$ in an oxygen atmosphere.

The dielectric constant $\left(\varepsilon_{\mathrm{r}}\right)$ and dissipation factor (loss tan $\delta$ ) were as a function of frequency in the range of $100 \mathrm{~Hz}-2 \mathrm{MHz}$ for the three thin film capacitors of the $\mathrm{Au} / \mathrm{BNF} / \mathrm{Pt}, \mathrm{Au} / \mathrm{BST} / \mathrm{Pt}$, and $\mathrm{Au} / \mathrm{BST} / \mathrm{BNF} / \mathrm{BST} / \mathrm{Pt}$ at RT. Figure 3 shows the dielectric properties of those thin film capacitors. For the $\mathrm{Au} / \mathrm{BNF} / \mathrm{Pt}$ film capacitor, the $\varepsilon_{\mathrm{r}}$ and loss tan $\delta$ decrease from 68 to 59 and from 0.141 to 0.052 with increasing frequency from $100 \mathrm{~Hz}$ to $2 \mathrm{MHz}$, respectively. In addition, for the $\mathrm{Au} / \mathrm{BST} / \mathrm{Pt}$ film capacitor, the $\varepsilon_{\mathrm{r}}$ decrease and loss tan $\delta$ increase from 341 to 331 and from 0.017 to 0.018 with increasing frequency from $100 \mathrm{~Hz}$ to $2 \mathrm{MHz}$, respectively. However, for the sandwich structure $\mathrm{Au} / \mathrm{BST} / \mathrm{BNF} / \mathrm{BST} / \mathrm{Pt}$ film capacitor, the $\varepsilon_{\mathrm{r}}$ and loss tan $\delta$ slightly decrease from 277 to 275 and 0.0045 to 0.0032 with increasing frequency from $100 \mathrm{~Hz}$ to $2 \mathrm{MHz}$. At $100 \mathrm{kHz}$, the $\varepsilon_{\mathrm{r}}$ and loss tan $\delta$ were 61 and 0.052, 334 and 0.018 , and 275 and 0.0033 , respectively for the three film capacitors of $\mathrm{Au} / \mathrm{BNF} / \mathrm{Pt}, \mathrm{Au} / \mathrm{BST} / \mathrm{Pt}$, and $\mathrm{Au} / \mathrm{BST} / \mathrm{BNF} / \mathrm{BST} / \mathrm{Pt}$. Use the single and double layers of BST thin films, the dielectric loss is suppressed in the $\mathrm{Au} / \mathrm{BST} / \mathrm{BNF} / \mathrm{BST} / \mathrm{Pt}$ thin film capacitors, the results are consistent with those of leakage current 
measurements. Most of the dielectric loss comes from conductivity loss. The equivalent resistance in multilayer thin films is equal to that in each layer, which reduces the dielectric loss of multilayer thin films [31].
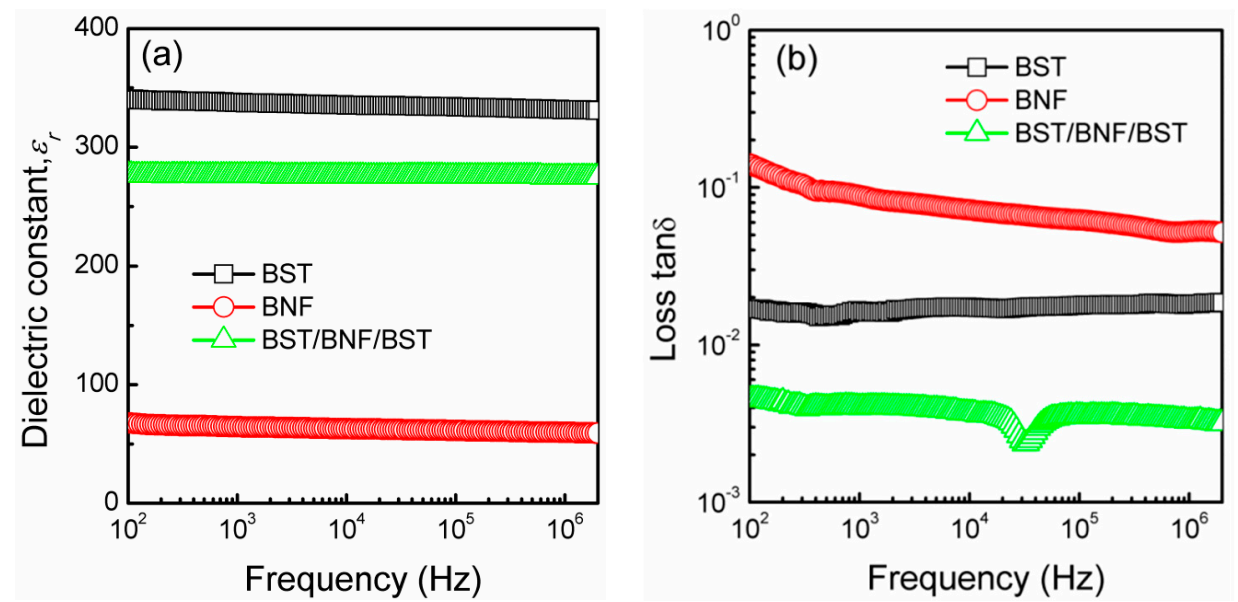

Figure 3. The dielectric constant (a) and loss $\tan \delta(\mathbf{b})$ versus frequency for BST, BNF and BST/BNF/BST films on $\mathrm{Pt}(111) / \mathrm{Ti} / \mathrm{SiO}_{2} / \mathrm{Si}(100)$ substrate measured at room temperatures.

In general, the equivalent capacitor of multilayer structure thin films may be expressed by series capacitors [32-34]. For the $\varepsilon_{\mathrm{r}}$ value of multilayer thin films, the effective capacitor was constructed by three capacitors, include of top $C_{\mathrm{BST}}, C_{\mathrm{BNF}}$, and bottom $C_{\mathrm{BST}}$ capacitors, respectively. Compared the reported about dissipation factor in $(\mathrm{Pb}, \mathrm{Sr}) \mathrm{TiO}_{3} /(\mathrm{Bi}, \mathrm{La}) \mathrm{FeO}_{3} /(\mathrm{Pb}, \mathrm{Sr}) \mathrm{TiO}_{3}$ trilayered structure [35], there is extremely low loss tan $\delta$ in the BST/BNF/BST thin films. In Figure $3 b$, the multilayers thin films have very low loss $\tan \delta$, the degree of the loss $\tan \delta$ was $\sim 10^{-3}$ from $100 \mathrm{~Hz}$ to $2 \mathrm{MHz}$. The bismuth's volatilization was limited in annealed processing by bottom and top BST layers, making the Bi/Fe in good station in BNF layer; it also improved the technology of preparation bringing down the defect rate of BST/BNF/BST film, and reducing the number of free-carriers.

In Figure 4, the typical polarization $(P)$-electric field $(E)$ hysteresis loops for the $\mathrm{Au} / \mathrm{BNF} / \mathrm{Pt}$ and $\mathrm{Au} / \mathrm{BST} / \mathrm{BNF} / \mathrm{BST} / \mathrm{Pt}$ thin film capacitors at RT and $250 \mathrm{~Hz}$. The inset of Figure 4 shows an unsaturated loose $P-E$ loop of the $\mathrm{Au} / \mathrm{BST} / \mathrm{Pt}$ thin layer capacitor, the remnant polarization $\left(P_{\mathrm{r}}\right)$, saturation polarization $\left(P_{\mathrm{s}}\right)$ and coercive field $\left(E_{\mathrm{c}}\right)$ were $0.223 \mu \mathrm{C} / \mathrm{cm}^{2}, 1.61 \mu \mathrm{C} / \mathrm{cm}^{2}$, and $20.3 \mathrm{kV} / \mathrm{cm}$, respectively. Bulk $\left(\mathrm{Ba}_{0.65} \mathrm{Sr}_{0.35}\right) \mathrm{TiO}_{3}$ material is cubic phase at room temperature, but due to the relaxor ferroelectric characteristics of small grain $\left(\mathrm{Ba}_{0.65} \mathrm{Sr}_{0.35}\right) \mathrm{TiO}_{3}$, it still has ferroelectric properties at room temperature and higher temperatures [36]. From Figures 1 and 4, the BST is cubic phase at room temperature, and the ferroelectric properties comes from the polar nanoregions $[37,38]$. For the Au/BST/BNF/BST/Pt trilayered film capacitor, the loop shows a slim shape and reaches saturation at low electric field (about $145 \mathrm{kV} / \mathrm{cm}$ ). It exhibited the $P_{\mathrm{r}}, P_{\mathrm{s}}$ and $E_{\mathrm{c}}$ were $3.77 \mu \mathrm{C} / \mathrm{cm}^{2}, 18.5 \mu \mathrm{C} / \mathrm{cm}^{2}$, and $21.7 \mathrm{kV} / \mathrm{cm}, 5.06 \mu \mathrm{C} / \mathrm{cm}^{2}$, $25.0 \mu \mathrm{C} / \mathrm{cm}^{2}$, and $18.3 \mathrm{kV} / \mathrm{cm}$, respectively for $\mathrm{Au} / \mathrm{BNF} / \mathrm{Pt}$ and $\mathrm{Au} / \mathrm{BST} / \mathrm{BNF} / \mathrm{BST} / \mathrm{Pt}$ thin film capacitors. These look like a banana ferroelectric for BNF and BST thin films [39], because the applied electric field is too low. When applied high electric field $(>600 \mathrm{kV} / \mathrm{cm})$, the $(\mathrm{Bi}, \mathrm{Nd}) \mathrm{FeO}_{3}$ thin films show good ferroelectricity [40,41]. From Figure 4, there a gap in the $P-E$ loop in $\mathrm{Au} / \mathrm{BNF} / \mathrm{Pt}$ thin film capacitor, indicating that the degree of leakage current in the $\mathrm{Au} / \mathrm{BNF} / \mathrm{Pt}$ film capacitor was much higher than that of the $\mathrm{Au} / \mathrm{BST} / \mathrm{BNF} / \mathrm{BST} / \mathrm{Pt}$ film capacitor. The ferroelectric enhancement in the BST/BNF/BST was owed to the coupling between BST and BFO thin films [18,35]. In addition, the remnant polarization, permittivity, and resistivity of $\mathrm{BFO}$ thin films have direct correlation with the $\mathrm{Bi} / \mathrm{Fe}$ ratio [42]. In this work, the bismuth's volatilization was inhibited by BST layers, which makes the Bi/Fe ratio in preferable situation and brings down the defect rate of the film improved the remnant polarization and saturation polarization. 


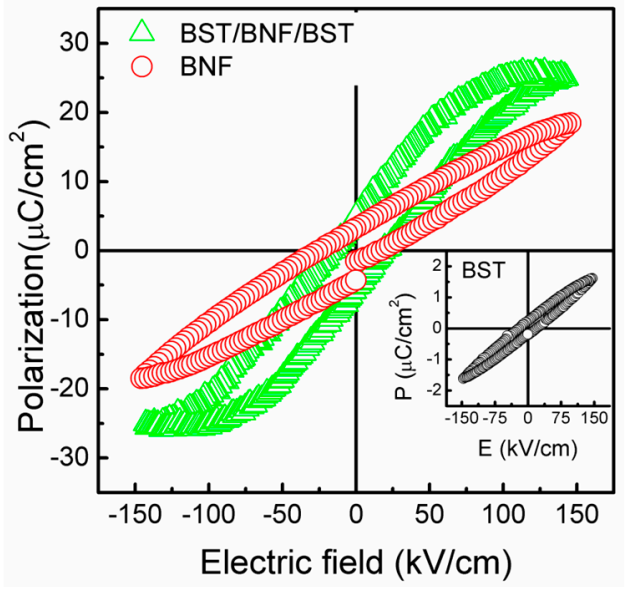

Figure 4. The typical $P-E$ hysteresis loops for the BNF and BST/BNF/BST films on $\mathrm{Pt} /(111) \mathrm{Ti} / \mathrm{SiO}_{2} / \mathrm{Si}(100)$ substrate at room temperature and $250 \mathrm{~Hz}$, the inset is the $P-E$ hysteresis loop of single layer BST thin film.

Figure 5 shows the leakage current density $(J)$-electric field $(E)$ characteristics of BST/BNF/BST and BNF film on (111) $\mathrm{Pt} / \mathrm{Ti} / \mathrm{SiO}_{2} / \mathrm{Si}$ substrate. The current demsity $(J)$ of BST/BNF/BST is $\sim 10^{-8} \mathrm{~A} / \mathrm{cm}^{2}$ at RT and $100 \mathrm{kV} / \mathrm{cm}$. Which is lower than that of the BNF film. In addition, in the BNF, the $J$ value increases rapidly with an increasing $E$ value. Scott et al. reported that the $J$ value of PZT films can be reduced by decreasing oxygen vacancies (OVs) [43], and they reduced the $\mathrm{Fe}^{3+}$ valance state in $\mathrm{BiFeO}_{3}$ film by annealed in nitrogen atmosphere $[29,44]$. In the quite low leakage current system, films annealed in oxygen can be reduced OVs in BST layers and the BST layers cut off the BNF layer with air reducing the $\mathrm{Fe}^{3+}$ valance state. Thus, the $J$ value was low due to reduced $\mathrm{OVs}$ and $\mathrm{Fe}^{3+}$ valance state. Moreover, the interface of ferroelectric BST layer and ferromagnetic BNF thin films plays an important role in the charge transfer between thin film and electrode interface and reducing the $J$ value.

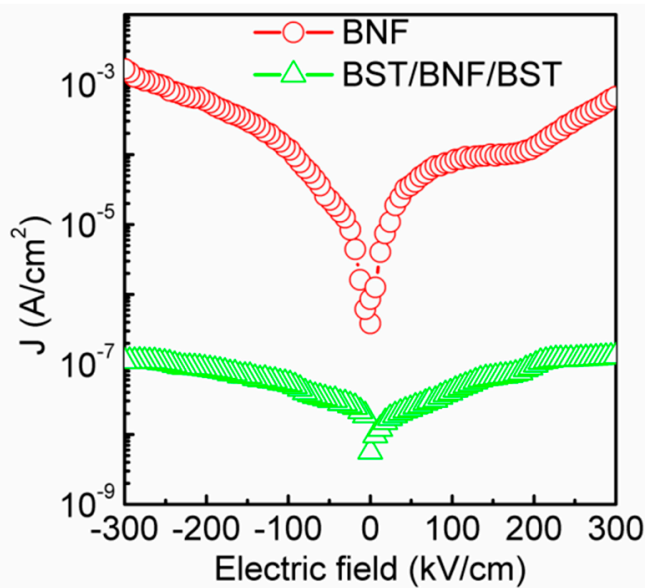

Figure 5. $J-E$ characteristics of $B N F$ and $B S T / B N F / B S T$ films on $\mathrm{Pt}(111) / \mathrm{Ti} / \mathrm{SiO}_{2} / \mathrm{Si}(100)$ substrate measured at room temperature.

Figure 6 shows the magnetization $(M)$-magnetic field $(H)$ loops of the BNF and BST/BNF/BST films on $\mathrm{Pt}(111) / \mathrm{Ti} / \mathrm{SiO}_{2} / \mathrm{Si}(100)$ substrates at RT. For the single layer BNF film, the inset of Figure 6 shows the loop in a slim shape and reaches saturation at low magnetic field (about $5 \mathrm{kOe}$ ). In the BST/BNF/BST thin film, there are higher remnant magnetization $\left(M_{\mathrm{r}}\right)$ and the lower coercive magnetic field (about $10.1 \mathrm{emu} / \mathrm{cm}^{3}$ and $\left.351 \mathrm{Oe}\right)$. The value of $M_{\mathrm{r}}$ is slightly larger than tha of the saturated magnetizations $\left(M_{\mathrm{s}}=7.14 \mathrm{emu} / \mathrm{cm}^{3}\right)$ for the PST/BLF/PST [35]. Thakuria and Joy reported that the $M_{\mathrm{s}}$ and $M_{\mathrm{r}}$ values of the nanocrystalline $\mathrm{Bi}_{0.875} \mathrm{Nd}_{0.125} \mathrm{FeO}_{3}$ are $\sim 1.3$ and $0.20 \mathrm{emu} / \mathrm{g}$, respectively [45]. Ederer et al. reported 
that the OVs can alter the magnetization slightly in the heterostructure $\mathrm{BiFeO}_{3} / \mathrm{Ba}_{0.25} \mathrm{Sr}_{0.75} \mathrm{TiO}_{3}$, and lead to the formation of $\mathrm{Fe}^{2+}$ [46]. The BST/BNF/BST film has a more optimized ferromagnetic than single BNF thin film that might be attributed to the bismuth's volatilization when inhibited by BST layers, bringing down the defect rate of BNF film and making the Bi/Fe in good station; the BST layers advanced the superexchange coupling of ferrite or double exchange of $\mathrm{Fe}^{2+}$ and $\mathrm{Fe}^{3+}$ ions and the incorporation of OVs in the BNF thin film play a key role in enhanced magnetization in BST/BNF/BST thin film.

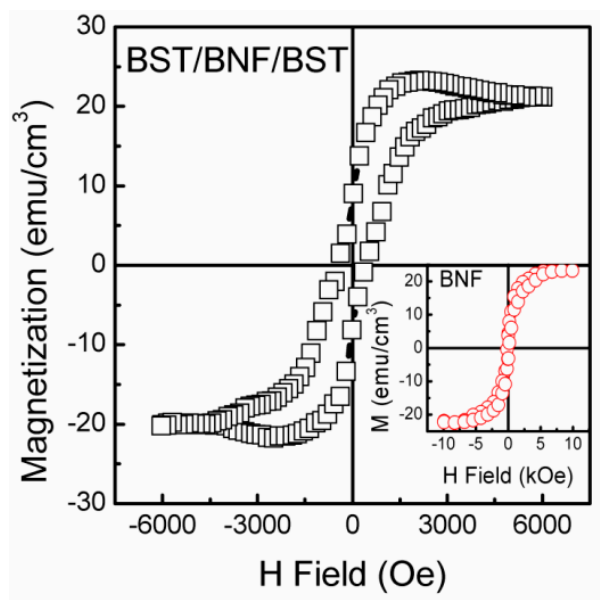

Figure 6. The $M-H$ hysteresis loop of the BST/BNF/BST film on $\mathrm{Pt}(111) / \mathrm{Ti} / \mathrm{SiO}_{2} / \mathrm{Si}(100)$ substrate at room temperature, the inset is the $M-H$ loop of single layer BNF thin film.

\section{Conclusions}

The sandwich structured BNF film with double BST layers grown on a $\mathrm{Pt}(111) / \mathrm{Ti} / \mathrm{SiO}_{2} / \mathrm{Si}(100)$ substrate was produced by radio frequency magnetron sputtering. The dielectric loss was suppressed and enhanced the multiferroic properties, respectively in the trilayered the films. The bismuth's volatilization by BST layers was limited and brought the Bi/Fe ratio to a desirable situation, maybe leading to quite low leakage current, dielectric loss, and high remnant polarization. It improved the technology of preparation, and by bringing down the defect rate of the BST/BNF/BST film, the leakage current and loss tan $\delta$ were $\sim 10^{-8} \mathrm{~A} / \mathrm{cm}^{2}$ at $200 \mathrm{kV} / \mathrm{cm}$ and $\sim 10^{-30}$, respectively. Moreover, the low leakage current density may be related to the role of BST in charge transfer between BNF and electrodes, involving the coupling reaction between BST and BNF films.

Author Contributions: Conceptualization, Z.-Y.W.; Formal Analysis, Z.-Y.W. and C.-B.M.; Investigation, Z.-Y.W. and C.-B.M.; Writing-Original Draft Preparation, Z.-Y.W. and C.-B.M.; Writing-Review and Editing, Z.-Y.W. and C.-B.M.

Funding: This research was funded by the "Guangdong Natural Science Fund Project of China (No. 2015A030313265)".

Conflicts of Interest: The authors declare no conflict of interest.

\section{References}

1. Catalan, G.; Scott, J.F. Physics and applications of bismuth ferrite. Adv. Mater. 2009, 21, 2463-2485. [CrossRef]

2. Gao, B.; Lin, L.; Chen, C.; Wei, L.; Wang, J.; Xu, B.; Li, C.; Bian, J.; Dong, S.; Du, J.; et al. Room-temperature ferromagnetic multiferroic $\mathrm{BiFe}_{0.5} \mathrm{Co}_{0.5} \mathrm{O}_{3}$ thin films with giant piezoelectric response. Phys. Rev. Mater. 2018, 2, 084401. [CrossRef]

3. Hojo, H.; Oka, K.; Shimizu, K.; Yamamoto, H.; Kawabe, R.; Azuma, M. Development of bismuth ferrite as a piezoelectric and multiferroic material by cobalt substitution. Adv. Mater. 2018, 30, 1705665. [CrossRef] [PubMed] 
4. Li, Z.; Yang, Z.; Wu, J.; Zhou, B.; Bao, Q.; Zhang, K.; Zhao, J.; Wei, J. Low leakage current resistive memory based on $\mathrm{Bi}_{1.10}\left(\mathrm{Fe}_{0.95} \mathrm{Mn}_{0.05}\right) \mathrm{O}_{3}$ films. Semicond. Sci. Technol. 2018, 33, 095002. [CrossRef]

5. Qi, H.; Wang, H.; Xu, X.; Tang, Y.; Xiao, P.; Xiao, M. Microstructure and electrical properties of ferroelectric $\mathrm{Bi}_{3.15} \mathrm{Nd}_{0.85} \mathrm{Ti}_{3} \mathrm{O}_{12} / \mathrm{BiFeO}_{3} / \mathrm{Bi}_{3.15} \mathrm{Nd}_{0.85} \mathrm{Ti}_{3} \mathrm{O}_{12}$ trilayered thin films on $\mathrm{Pt} / \mathrm{Ti} / \mathrm{SiO} / \mathrm{Si}$. J. Mater. Sci. Mater. Electron. 2017, 28, 13757-13762. [CrossRef]

6. Liu, G.; Wang, C.; Wang, C.; Qiu, J.; He, M.; Xing, J.; Jin, K.; Lu, H.; Yang, G. Effects of interfacial polarization on the dielectric properties of $\mathrm{BiFeO}_{3}$ thin film capacitors. Appl. Phys. Lett. 2008, 92, 122903. [CrossRef]

7. Hong, N.H.; Huong, N.T.; Kim, T.-Y.; Goumri-Said, S.; Kanoun, M.B. Tuning magnetic properties of $\mathrm{BiFeO}_{3}$ thin films by controlling rare-earth doping: Experimental and first-principles studies. J. Phys. Chem. C 2015, 119, 14351-14357.

8. Wang, L.; Yang, S.; Zhang, F.; Fan, S. Perfection of leakage and ferroelectric properties of Ni-doped $\mathrm{BiFeO}_{3}$ thin films. Micro Nano Lett. 2018, 13, 502-505. [CrossRef]

9. Sun, W.; Zhou, Z.; Luo, J.; Wang, K.; Li, J. Leakage current characteristics and Sm/Ti doping effect in $\mathrm{BiFeO}_{3}$ thin films on silicon wafers. J. Appl. Phys. 2017, 121, 064101. [CrossRef]

10. Yang, S.; Zhang, F.; Xie, X.; Sun, H.; Zhang, L.; Fan, S. Enhanced leakage and ferroelectric properties of Zn-doped $\mathrm{BiFeO}_{3}$ thin films grown by sol-gel method. J. Alloy. Compd. 2018, 734, 243-249. [CrossRef]

11. Zhou, Z.; Sun, W.; Liao, Z.; Ning, S.; Zhu, J.; Li, J. Ferroelectric domains and phase transition of sol-gel processed epitaxial Sm-doped $\mathrm{BiFeO}_{3}$ (001) thin films. J. Mater. 2018, 4, 27-34.

12. Golovina, I.S.; Falmbigl, M.; Plokhikh, A.V.; Parker, T.C.; Johnson, C.; Spanier, J.E. Effect of annealing conditions on the electrical properties of ALD-grown polycrystalline $\mathrm{BiFeO}_{3}$ films. J. Mater. Chem. C 2018, 6, 5462-5472. [CrossRef]

13. Zhang, Y.; Wang, Y.; Qi, J.; Tian, Y.; Sun, M.; Zhang, J.; Hu, T.; Wei, M.; Liu, Y.; Yang, J. Enhanced magnetic properties of $\mathrm{BiFeO}_{3}$ thin films by doping: analysis of structure and morphology. Nanomaterials 2018, 8, 711. [CrossRef] [PubMed]

14. Sharif, S.; Murtaza, G.; Meydan, T.; Williams, P.I.; Cuenca, J.; Hashimdeen, S.H.; Shaheen, F.; Ahmad, R. Structural, surface morphology, dielectric and magnetic properties of holmium doped $\mathrm{BiFeO}_{3}$ thin films prepared by pulsed laser deposition. Thin Solid Films 2018, 662, 83-89. [CrossRef]

15. Zhang, X.; Wang, P.; Sheng, S.; Xu, F.; Ong, C.K. Ferroelectric $\mathrm{Ba}_{x} \mathrm{Sr}_{1-x} \mathrm{TiO}_{3}$ thin film varactors with parallel plate and interdigital electrodes for microwave applications. J. Appl. Phys. 2008, 104, 124110. [CrossRef]

16. Lee, J.M.; Kang, S.Y.; Shin, J.C.; Kim, W.J.; Hwang, C.S.; Kim, H.J. Improvements in electrical properties of $(\mathrm{Ba}, \mathrm{Sr}) \mathrm{TiO}_{3}$ capacitor with chemical vapor deposited Pt top electrode using Pt hexafluoroacetylacetonate. Appl. Phys. Lett. 1999, 74, 3489-3491. [CrossRef]

17. Xiong, H.; Tang, X.; Jiang, L.; Chan, H.L.W. Enhanced dielectric properties of nanocrystalline $\left(\mathrm{Ba}_{0.65} \mathrm{Sr}_{0.35}\right) \mathrm{TiO}_{3}$ thin films grown on $\mathrm{CaRuO}_{3}$ bottom layer. J. Nanosci. Nanotech. 2009, 9, 5834-5838. [CrossRef] [PubMed]

18. Miao, J.; Chew, K.-H.; Zhang, J.X.; Zhan, Q.; Xu, X.G.; Jiang, Y. Enhanced fatigue and ferroelectric properties in multiferroic $\left(\mathrm{Ba}_{0.7} \mathrm{Sr}_{0.3}\right) \mathrm{TiO}_{3} /\left(\mathrm{Bi}_{1.05} \mathrm{La}_{0.05}\right) \mathrm{FeO}_{3}$ epitaxial heterostructures. Appl. Phys. Lett. 2013, 102, 232902. [CrossRef]

19. Feng, Y.; Wang, C.; Tian, S.L.; Zhou, Y.; Ge, C.; Guo, H.Z.; He, M.; Jin, K.; Yang, G. Effects of BaTiO 3 and $\mathrm{SrTiO}_{3}$ as the buffer layers of epitaxial $\mathrm{BiFeO}_{3}$ thin films. Sci. China Phys. Mech. Astron. 2017, 60, 067711. [CrossRef]

20. Zhang, T.; Tang, X.; Liu, Q.; Jiang, Y.; Lai, J. Improved electric property in $\mathrm{SrTiO}_{3}-\mathrm{Bi}_{2} \mathrm{NiMnO}_{6}-\mathrm{SrTiO}_{3}$ sandwich structural thin films. Superlattices Microstruct. 2015, 85, 653-657. [CrossRef]

21. Guo, E.J.; Herklotz, A.; Roth, R.; Christl, M.; Das, S.; Widdra, W.; Dörr, K. Tuning the switching time of $\mathrm{BiFeO}_{3}$ capacitors by electrodes' conductivity. Appl. Phys. Lett. 2013, 103, 022905. [CrossRef]

22. Guo, E.J.; Das, S.; Herklotz, A. Enhancement of switching speed of $\mathrm{BiFeO}_{3}$ capacitors by magnetic fields. APL Mater. 2014, 2, 096107. [CrossRef]

23. Chen, Z.; Chen, Z.; Kuo, C.; Tang, Y.; Dedon, L.R.; Li, Q.; Zhang, L.; Klewe, C.; Huang, Y.-L.; Prasad, B.; et al. Complex strain evolution of polar and magnetic order in multiferroic $\mathrm{BiFeO}_{3}$ thin films. Nat. Commun. 2018, 9, 3764. [CrossRef] [PubMed]

24. Khabiri, G.; Anokhin, A.S.; Bunina, O.A.; Golovko, Y.I.; Mukhortov, V.M.; Shirokov, V.B.; Yuzyuk, Y.I.; Simon, P. Structure and lattice dynamics of heterostructures based on bismuth ferrite and barium strontium titanate. Phys. Solid State 2013, 55, 2506-2515. [CrossRef] 
25. Stryukov, D.V.; Razumnaya, A.G.; Golovko, Y.I.; Anokhin, A.S.; Lukyanchuk, I.A.; Shirokov, V.B.; Mukhortov, V.M. Lattice dynamics and structural distortions in the multiferroic (Ba,Sr) $\mathrm{TiO}_{3} /(\mathrm{Bi}, \mathrm{Nd}) \mathrm{FeO}_{3}$ heterostructures. Thin Solid Films 2017, 636, 220-224. [CrossRef]

26. Liang, D.; Li, X.; Wang, J.; Wu, L.; Chen, P. Light-controlled resistive switching characteristics in $\mathrm{ZnO} / \mathrm{BiFeO}_{3} / \mathrm{ZnO}$ thin film. Solid State Electron. 2018, 145, 46-48. [CrossRef]

27. Greculeasa, S.G.; Schinteie, G.; Hrib, L.M.; Stancu, V.; Pasuk, I.; Kuncser, A.; Kuncser, V. Complex exchange coupling mechanisms in SRO/BFO/Fe heterostructures. J. Alloy. Compd. 2019, 773, 338-345. [CrossRef]

28. Zou, Y.; Liu, Q.; Tong, J.; Jiang, Y.; Xiong, D.; Tang, X.; Zhou, Y. Effects of annealing temperature on magnetic properties of $\mathrm{Bi}_{0.9} \mathrm{Nd}_{0.1} \mathrm{FeO}_{3}$ thin films. Surf. Coat. Technol. 2013, 229, 120-124. [CrossRef]

29. Ma, C.; Tang, X.; Chen, D.; Liu, Q.; Jiang, Y.; Xiong, D.; Zhou, Y. Reduced leakage current and enhanced magnetic properties of $(\mathrm{Bi}, \mathrm{Nd}) \mathrm{FeO}_{3}$ thin films grown on $(\mathrm{Ba}, \mathrm{Sr}) \mathrm{TiO}_{3}$ bottom layer. Funct. Mater. Lett. 2012, 5, 1250032. [CrossRef]

30. Wang, Y.; Tang, X.; Chen, D.; Liu, Q.; Jiang, Y.; Xiong, D. Influence of sputtering atmosphere on the structural and magnetic properties of $\left(\mathrm{Bi}_{1-x} \mathrm{Nd}_{x}\right) \mathrm{FeO}_{3}$ thin films. Vacuum 2014, 107, 108-111. [CrossRef]

31. Lee, H.N.; Christen, H.M.; Chisholm, M.F.; Rouleau, C.M.; Lowndes, D.H. Strong polarization enhancement in asymmetric three-component ferroelectric superlattices. Nature 2005, 434, 792. [CrossRef]

32. Stengel, M.; Spaldin, N.A. Origin of the dielectric dead layer in nanoscale capacitor. Nature 2006, 443, 679-682. [CrossRef] [PubMed]

33. Campbell, D.S.; Hayes, J.A. Capacitive and Resistive Electronic Components; CRC Press: Boca Raton, FL, USA, 1994; p. 122.

34. Zhou, J.; Liu, C.; Li, R.; Chen, W. Effects of heterogeneous interfaces on microstructure and dielectric properties of $\mathrm{Ca}\left(\mathrm{Mg}_{1 / 3} \mathrm{Nb}_{2 / 3}\right) \mathrm{O}_{3} / \mathrm{CaTiO}_{3}$ multilayered thin films. Acta Phys. Sin. 2012, 61, 421-427. (In Chinese)

35. Liu, Q.; Miao, J.; Shao, F.; Ji, Y.; Ren, Z.; Chen, J.; Wu, Y.; Xu, X.; Meng, K.; Jiang, Y. Heteroepitaxial $\mathrm{Pb}_{0.9} \mathrm{Sr}_{0.1} \mathrm{TiO}_{3} / \mathrm{Bi}_{0.9} \mathrm{La}_{0.1} \mathrm{FeO}_{3} / \mathrm{Pb}_{0.9} \mathrm{Sr}_{0.1} \mathrm{TiO}_{3}$ multiferroic structure: an effective way to improve the electrical, ferroelectric and magnetic performance. J. Mater. Sci. Mater. Electron. 2016, 27, 8080-8086. [CrossRef]

36. Ge, P.; Tang, X.; Liu, Q.; Jiang, Y.; Li, W.; Luo, J. Energy storage properties and electrocaloric effect of $\mathrm{Ba}_{0.65} \mathrm{Sr}_{0.35} \mathrm{TiO}_{3}$ ceramics near room temperature. J. Mater. Sci. Mater. Electron. 2018, 29, 1075-1081. [CrossRef]

37. Pandya, S.; Wilbur, J.; Kim, J.; Gao, R.; Dasgupta, A.; Dames, C.; Martin, L.W. Pyroelectric energy conversion with large energy and power density in relaxor ferroelectric thin films. Nat. Mater. 2018, 17, 432-438. [CrossRef]

38. Miao, J.; Chew, K.-H.; Zhang, L.X.; Wu, R.; Wang, J.O.; Shao, F.; Zhan, Q.; Jiang, Y. Coexistence of dielectric relaxation and magnetic relaxation in compressively strained $\mathrm{BiFeO}_{3} / \mathrm{Ba}_{0.7} \mathrm{Sr}_{0.3} \mathrm{TiO}_{3}$ superlattices. Appl. Phys. Lett. 2019, 114, 112902. [CrossRef]

39. Scott, J.F. Ferroelectrics go bananas. J. Phys. Condens. Matter 2008, 20, 021001. [CrossRef]

40. Hu, Z.; Li, M.; Yu, B.; Pei, L.; Liu, J.; Wang, J.; Zhao, X. Enhanced multiferroic properties of BiFeO ${ }_{3}$ thin films by Nd and high-valence Mo co-doping. J. Phys. D Appl. Phys. 2009, 42, 185010. [CrossRef]

41. Ukai, Y.; Yamazaki, S.; Kawae, T.; Morimoto, A. Polarization-induced photovoltaic effects in Nd-doped $\mathrm{BiFeO}_{3}$ ferroelectric thin films. Jpn. J. Appl. Phys. 2012, 51, 09LE10. [CrossRef]

42. You, L.; Chua, N.T.; Yao, K.; Chen, L.; Wang, J. Influence of oxygen pressure on the ferroelectric properties of epitaxial $\mathrm{BiFeO}_{3}$ thin films by pulsed laser deposition. Phys. Rev. B 2009, 80, 024105. [CrossRef]

43. Scott, J.F.; Araujo, C.A.; Melnick, B.M.; McMillan, L.D.; Zuleeg, R. Quantitative measurement of space-charge effects in lead zirconate-titanate memories. J. Appl. Phys. 1991, 70, 382-388. [CrossRef]

44. Singh, S.K.; Tomy, C.V.; Era, T.; Itoh, M.; Ishiwara, H. Improved multiferroic properties in Sm-doped $\mathrm{BiFeO}_{3}$ thin films deposited using chemical solution deposition method. J. Appl. Phys. 2012, 111, 102801. [CrossRef]

45. Thakuria, P.; Joy, P.A. High room temperature ferromagnetic moment of Ho substituted nanocrystalline $\mathrm{BiFeO}_{3}$. Appl. Phys. Lett. 2010, 97, 162504. [CrossRef]

46. Ederer, C.; Spaldin, N.A. Influence of strain and oxygen vacancies on the magnetoelectric properties of multiferroic bismuth ferrite. Phys. Rev. B 2005, 71, 224103. [CrossRef]

(C) 2019 by the authors. Licensee MDPI, Basel, Switzerland. This article is an open access article distributed under the terms and conditions of the Creative Commons Attribution (CC BY) license (http://creativecommons.org/licenses/by/4.0/). 